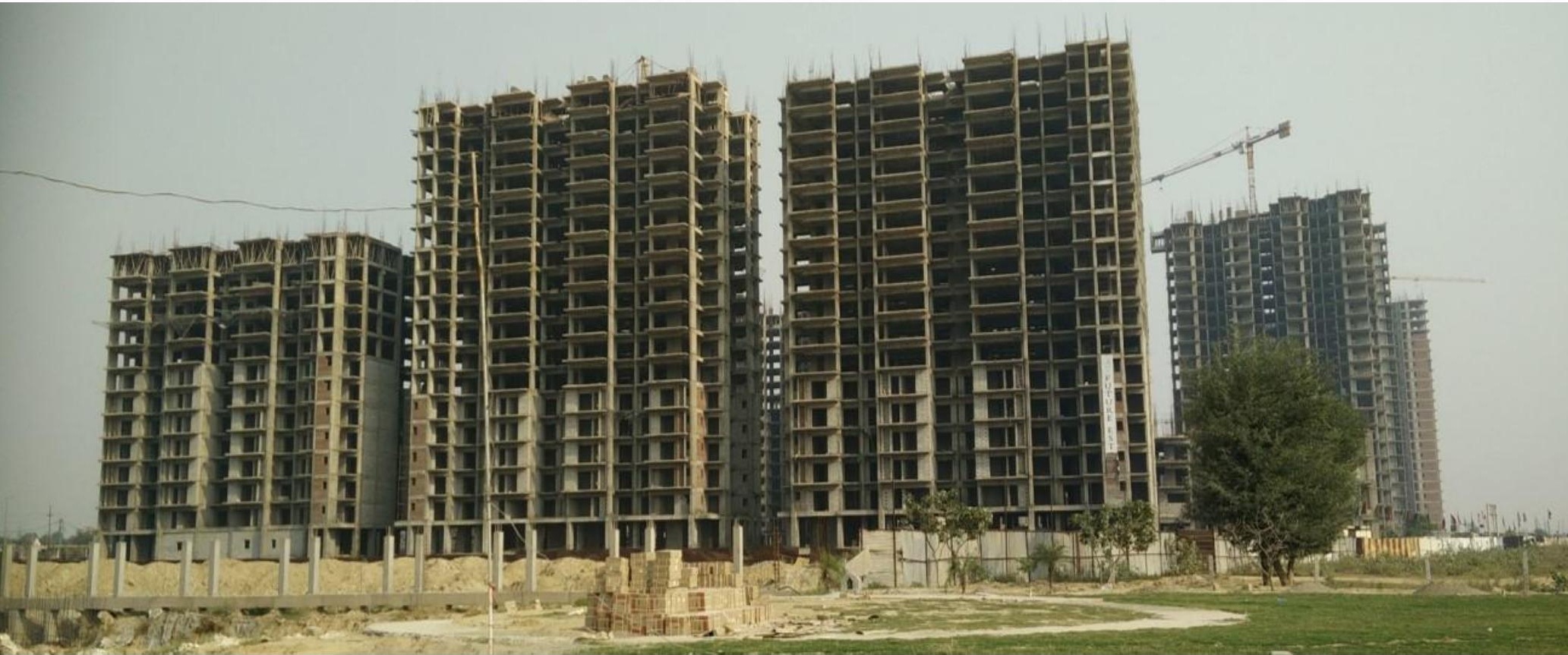

\title{
REAL ESTATE REGULATION: IRONING OUT DIFFICULTIES IN IMPLEMENTING THE REAL ESTATE (REGULATION AND DEVELOPMENT) ACT, 2016
}

\section{Introduction}

The regulation of the real estate sector to protect the interests of the buyer has been the focus of state governments ever since the private sector became involved in the development and sale of real estate. Until recently, this regulation mostly took the form of legislations meant to impose certain mandatory conditions on real estate promoters. However, there was very little compliance to the regulatory framework, and violations of legal requirements became commonplace. A deep trust deficit came to exist between real estate promoters and buyers.

In 2011, the Competition Commission, in its main order in Belaire Owners' Association v. DLF Ltd. and others, ${ }^{i}$ observed that
The absence of any single sectoral regulator to regulate the real estate sector in totality, so as to ensure adoption of transparent and ethical business practices and protect the consumers, has only made the situation in the real estate sector worse.

At the time the Commission issued this order, the Ministry of Housing and Urban Poverty Alleviation, Government of India, had already drafted a Model Real Estate (Regulation of Development) Act, to serve as a template for the states to enact their own versions of this model legislation. The Act prescribed the creation of a Real Estate Regulatory Authority as a sector-specific regulator. This draft legislation was the precursor to the Real Estate (Regulation and Development) Act, 2016. 
Regulatory Framework under the Real Estate (Regulation and Development) Act

The Act was brought into force in phases-only sections 2,20 to 39,41 to 58,71 to 78 , and 81 to 92 came into force on 1 May 2016. All the other sections of the Act were brought into force only on 1 May 2017.

The sections that came into force in 2016 imposed strict timelines on state governments to set up the prescribed regulatory framework: a Real Estate Regulatory Authority (RERA) and a corresponding appellate tribunal. The working of these institutions was to be defined by a set of rules framed by each state government, whereas their internal functioning was to be taken care of by a set of regulations drafted by the regulatory authority itself.

The state governments were required to notify the rules under the Act within six months of it coming into force, and set up a regulatory authority and appellate tribunal within a year. Once this regulatory framework has been established all promoters would compulsorily have to register each real estate project with the regulatory authority. This includes even government bodies and agencies which are involved in the development and sale of real estate. Any real estate project must be registered before initiating any marketing, booking or sale process for the project.

Despite the strict timelines for the implementation of the Act, several states shot well beyond the deadlines in notifying the rules under the Act. A major dilemma for the states was with respect to the treatment of real estate projects that were ongoing when the Act was brought into force. While the Act itself is clear on the status of such projects, the states have flouted the provisions of the Act in providing real estate promoters with the leeway to exclude their ongoing projects from its ambit.
Other issues with the drafting of the provisions of the Act are emerging in light of their implementation.

In February 2018, the Indian Institute for Human Settlements (IIHS) organised a stakeholder consultation on the implementation of the Real Estate (Regulation and Development) Act, 2016, to discuss the teething difficulties being faced by all stakeholders affected by the Act. These problems included different standards being adopted by different states in their treatment of ongoing real estate projects, and an overwhelming bias in favour of buyers, leaving room for these buyers to exploit some of the provisions. This policy brief summarises the issues and recommendations that were put forth as part of this stakeholder consultation exercise.

\section{Issues and Recommendations}

\section{Delays in the registration of 'ongoing' projects with the RERAs}

Section 4 of the Act lays down that a project must have received a commencement certificate to qualify for registration with the RERA and to begin to receive funds from prospective buyers. However, there have been many instances where a promoter has received funds from the buyer without a commencement certificate. This creates a peculiar situation vis-à-vis registration with the RERA since this certificate is a prerequisite for registration.

\section{Recommendations}

- The definition of 'ongoing projects' as contained in the rules drafted by the different states must be amended to exclude projects where the structures are fit for occupation but a completion certificate has not been obtained. 
- In the interim, given that the Act does not allow for any deviations from the basic requirements for obtaining a completion certificate, all exemption rules notified by the states that depart from this standard are illegal and hence cannot be enforced.

\section{Inadequate time to complete the conveyance of a project under the Act}

Section 17 of the Act mandates that the promoter must complete the conveyance of a project in favour of the allottees within three months of receiving the occupancy certificate. This period is deemed to be too short by promoters. They claim that while it is presumed that promoters seek to avoid conveyance in order to retain a stake in the project, the conveyance-avoiding behaviour of the allottees has not been adequately accounted for by the Act. Allottees seek to avoid the conveyance of a project so that the promoter continues to be responsible for carrying out maintenance and repair works for as long as possible. In the face of such behavior, it may be very difficult for promoters to realistically meet the three-month deadline set under the Act.

\section{Recommendation}

- The promoter must be allowed between six months to one year from receipt of the completion certificate to complete conveyance to the association of allottees.

\section{Issues with the drafting of the law}

- The Act erroneously places 'structural defects' and 'bad workmanship' in the same basket when it comes to allowing the buyer to trigger the compensation clause within a five-year period.
Section 14(3) of the Act lays down that the promoter must rectify any structural defect or any other defect in workmanship, quality or provision of services within 30 days of the buyer bringing it to their notice. The Act provides the buyer a five-year window within which such defects can be brought up. 'Structural defects' refer to defects in the entire structure, i.e. the building. On the other hand, 'workmanship' refers to defects within the unit, which the allottee must identify within a year of taking possession of the unit. Despite the difference between the two kinds of deficiencies, the Act, in giving the allottee so much time to bring them to the notice of the promoter, places a disproportionately heavy burden on the promoter.

- Section 18 of the Act allows the allottee to claim applicable interest in the event that the promoter is unable to complete the project according to the terms of the agreement for sale. This indicates a lack of emphasis on the completion of the project, which could be perceived as encouragement by an allottee to claim applicable interest in the event of a delay. This provision could pose problems in the future, especially during lean periods for the real estate market, which could cause the market value of a project to depreciate. In such an event, allottees would be likely avail the option of getting their money back with interest, as opposed to pushing for the completion of the project. 


\section{Recommendations}

- The Act should include a provision for mandatory third-party inspection of the project at the time of handover of possession.

- While the time period allowed for claims against structural defects should be five years, this should be applicable from the date of completion of the project and not the date of handover of possession. On the other hand, the time period for allowing claims against bad workmanship should be limited to one year from the date of handing over possession to the allottee.

\footnotetext{
' CCl, Case 19 of 2010, Date of Order: 12.8.2011
}

- The language of the Act must be suitably amended to encourage the completion of the project.

- The time period allowed to the allottee to claim interest for the period of delay must be limited to a period of one year from the stated date of completion. The option given to the allottee to walk out of the project after receiving a refund with interest must be allowed only in certain restricted circumstances. 